\author{
Dr. sc. Duško Lozina, redoviti profesor \\ Pravnog fakulteta Sveučilišta u Splitu \\ Ivana Jerkić, mag. iur.
}

\title{
REFLEKSIJE O LOKALNOJ HRVATSKOJ SAMOUPRAVI
}

\author{
UDK: 352. (497.5) \\ Primljeno: 20. 07. 2018. \\ Pregledni znanstveni rad
}

\begin{abstract}
Osnovna nakana ovoga rada jest pokazati neke od magistralnih puteva kroz koje prolazi sustav lokalne samouprave u Republici Hrvatskoj. Proces europeizacije, naime, sve više zahvaća i oblikuje hrvatsku lokalnu samoupravu, uključujući implementaciju novih standarda rada kao što su procesi decentralizacije i dekoncentracije, privatizacije, liberalizacije, deregulacije, javnosti, transparentnosti i otvorenosti, te specijalizacije, informatizacije i digitalizacije itd. To su temeljne vrijednosti upravnih doktrina poput novog javnog menadžmenta, ,dobre vladavine“ i drugih. U kontekstu ove teme posebnu pozornost stavili smo na neke aspekte organizacijske strukture Splitskodalmatinske županije apostrofirajući pritom posebice podatke o kvalifikacijskoj, spolnoj i dobnoj strukturi zaposlenih u upravnim tijelima županije i neke pokazatelje o financijsko-proračunskom kapacitetu općina, gradova i same županije.
\end{abstract}

Ključne riječi: lokalna samouprava, upravne doktrine, vrijednosti u lokalnoj samoupravi, financijsko-proračunski kapacitet, europeizacija

Hrvatska lokalna i područna (regionalna) samouprava prošla je u svom relativno kratkom razdoblju postojanja kroz nekoliko važnih perioda razvoja. Općenito, može se kazati da je to bio trnovit put od centraliziranog modela lokalne samouprave koji je utemeljen u vrijeme Domovinskog rata, pa do snažnog i gotovo jedinstvenog zahtjeva upravne struke i teorije da taj razvoj dobije decentralizacijska obilježja. U tom smislu, možemo bez sustezanja ustvrditi da je hrvatska upravna znanost i u ovom segmentu pokazala veliku odgovornost i elasticitet u praćenju recentnih europskih, ali i širih teorijskih spoznaja.

To se prije svega odnosi na recepciju najnovijih znanja iz područja javne, državne i lokalne (regionalne) (samo)uprave što se odnosi na spoznaje i naputke koje promiču najrazvijenije europske zemlje i anglosaksonska upravna teorija i praksa. Tu prvenstveno mislimo na snažno naglašavanje vrijednosti koje zagovaraju koncepti novog javnog menadžmenta, ,dobre vladavine“, ali i činjenice da weberijanske vrijednosti uprave bivaju amalgamirane s naprijed navedenim teorijskim koncepcijama.

Široko se prihvaćaju ideje poput decentralizacije i dekoncentracije, participacije građana, javnosti, transparentnosti i otvorenosti, specijalizacije i koordinacije, 
pristupa javnim informacijama, zaštiti podataka, inovacija i druge. Može se kazati da se težište proučavanja pomiče od klasičnog koncepta Rechtsstaat u kojemu je država središnja integracijska sila unutar društva, prema takvim stajalištima koja naglašavaju važnost ,javnog interesa“ koji zahtijeva manje ekstenzivnu državu ili pak njezinu minimalnu ulogu unutar društvenog prostora, što je posebice slučaj s anglosaksonskim državama, kao što su Australija, Novi Zeland i Velika Britanija. ${ }^{1}$ Kvintesencija takvih stajališta odražava se u radikalnom zaokretu od modela socijalne države do nastanka regulatorne države ili čak tzv. lean-state.

Naravno da nisu nevažna ni ona teorijska stajališta koja kritički promišljaju osnovna načela novog javnog menadžmenta, kao što su učinkovitost, upravljanje kvalitetom i drugi postulati te doktrine, smatrajući da su politički i administrativni sustavi u zapadnim demokracijama utemeljeni na složenom skupu normi i vrijednosti koje balansiraju u različitim i često ambigvitetnim putovima (smjerovima). ${ }^{2}$

Važnu ulogu na strukturu hrvatske lokalne samouprave odigrala su mnogobrojna izvješća, ocjene i preporuke SIGME i Europske komisije. Hrvatska lokalna samouprava prošla je i prolazi složeni put ka europeizaciji, što znači harmonizaciji i konvergenciji s upravnom stečevinom Unije.

Koncept europeizacije podrazumijeva veći broj različitih sadržaja, a sažeto iskazano, bavi se trima ključnim pitanjima koja se prostorno mogu odrediti kao vertikalni pristup odozdo-gore, vertikalni pristup odozgo-dolje, te horizontalni pristup. Ipak, većina autora smatra da je „najčešće korištenje koncepta europeizacije ono koje u fokus stavlja institucionalne promjene u državama članicama i pristupnicama pod utjecajem Europske unije.“"3

U kontekstu ovih razmišljanja ne treba u potpunosti zanemariti ni burnu i bogatu povijest institucija lokalne samouprave na tlu Hrvatske, navlastito od razdoblja države hrvatskih narodnih vladara iz 10. - 12. stoljeća kada se javljaju župe i seoske zadruge kao temeljni oblici organizacije teritorija, pa sve do utemeljenja županija i slobodnih kraljevskih gradova na području Banovina Hrvatske i Slavonije, pa s tim u svezi B. Babac kaže da „u slučaju hrvatskom riječ je o tradiciji lokalne i regionalne samouprave koja se izražava kroz historički županijski ustroj (Régime historique de Comtes Croate). To je 'narodna pravna tradicija kao i prvenstveno vrelo prava te pravnih shvaćanja i osjećaja', ne samo bitnim počelom već moglo bi

1 Više o tom procesu pogledati u: Pollitt, Christopher - Bouckaert, Geert: Public Management Reform - A comparative analysis, Oxford University Press, 2004. O značaju kreativnosti kao važne vrijednosti za lokalnu samoupravu vidi primjerice tekst: Kruiyen, M. Peter - Genugten van, Marieke: „Creativity in Local Government: Definition and determinants“, Public Administration, No. 3/vol. 95., Wiley, Singapore, 2017., str. 825-841.

2 Christensen, Tom - Laegred, Per: Transcending New Public Management, The transformation of Public Sector Reforms, Ashgate Publishing Limited, Survay England, 2009., str. 17.

3 Pogledati više u poglavlju ,Teorija europeizacije“ u knjizi: Europski upravni prostor, Koprić, Ivan - Musa, Anamarija - Lalić, Novak, Goranka, Institut za javnu upravu, Zagreb, 2012., str. 63-70. 
se reći okosnicom one 'pozitivne hrvatske državno-pravne tradicije' što ju naglašuje hrvatski ustav. ${ }^{\text {“4 }}$

U Dalmaciji pak prevladavaju statuti srednjovjekovnih komuna, kao svojevrsni „mali ustavi“" tih urbaniteta, koji su svojim normama pokrivali puninu ukupnog društvenog života, ljubomorno čuvajući taj „zatvoreni“ komunalni svijet od mogućih izvanjskih napadaja.

I dok je hrvatska lokalna samouprava 90-ih godina prošlog stoljeća bila pod utjecajem francuskog modela organizacije državne i lokalne samouprave, u svom daljnjem utemeljenju ona se sve više približava njemačkom modelu organizacije lokalne samouprave.

Kao osnovne komponente harmonizacije lokalne samouprave na europskom planu Koprić posebice naglašava ove:

- $\quad$ izravno biranje čelnika jedinica lokalne samouprave od strane građana;

- lokalna samouprava vidi se kao instrument za rješavanje problema u zajednici;

- $\quad$ ujednačava se krug poslova koje obavljaju lokalne jedinice za svoje stanovništvo;

- lokalne jedinice sve više postaju potpora i poticaj ekonomskom razvoju određenog područja; jedinica;

dolazi do diverzifikacije po instrumentima i oblicima financiranja lokalnih

- dolazi do privatizacije komunalnih usluga koji proces sve više napreduje što se vidi i u rješenjima hrvatskog Zakona o komunalnom gospodarstvu (op. D. L.);

- $\quad$ regionalni koncept razvoja sve se više naglašava kao učinkovitije rješenje od tradicijskog županijskog sustava;

- gradovima se posvećuje sve veća pozornost kao generatorima razvoja šireg okolnog prostora - nastaju tzv. pametni gradovi;

- $\quad$ širi se suradnja različitih razina vlasti i višerazinsko (multi-level) upravljanje. ${ }^{5}$

Lokalna samouprava per se počiva na nekoliko osnovnih kriterija. To su politički, ekonomsko-financijski, kadrovski (pitanje upravljanja ljudskim potencijalima), demografski koji zbog naraslih depopulacijskih procesa u Hrvatskoj, ali i u širem okolišu, postaje jednim od determinirajućih za budući razvoj lokalne samouprave, zatim već spomenuti međunarodnopravni (značaj Europske povelje o lokalnoj samoupravi) itd.

4 Babac, Branko: „Oblikovanje hrvatskoga regionalnog političko-regionalnog, političko-upravnog ustrojstva u razmeđu suvremenosti nacionalne tradicije i europeizacije - prethodni iskazi“, u Zborniku radova Teritorijalni ustroj i regionalizacija RH u kontekstu europskih integracija, PFS, Split, 2010., str. 53-84.

5 Koprić, Ivan: Suvremeni trendovi u razvoju lokalne samouprave, Institut za javnu upravu, Priručnici za stručno usavršavanje, Zagreb, 2018., str. 11-12. 


\section{ASPEKTI LOKALNE SAMOUPRAVE U REPUBLICI HRVATSKOJ}

Lokalna samouprava kao institucija javlja se u RH u vrijeme Domovinskog rata i kao takva zamijenila je dotadašnji komunalni sustav koji je egzistirao gotovo pola stoljeća i bio utemeljen na velikim jedinicama koje su u prosjeku brojile preko 40.000 stanovnika.

Hrvatska, po pokazateljima iz 2016. godine, ima ukupno 428 općina, 128 gradova te 20 županija, kojima treba pridodati Grad Zagreb koji ima istodobno status Grada i Županije.

Najveća hrvatska županija po teritorijalnom obuhvatu jest Ličko-senjska županija koja ima $5353 \mathrm{~km} 2$, ali, po popisu stanovništva iz 2011. godine, i svega 50.927 stanovnika, dakle 9,5 stanovnika na km2 površine, 4 grada, 8 općina i 258 naselja. Kao što vidimo iz ovih egzaktnih pokazatelja županija i njihove organizacije, smatramo da postoje utemeljeni razlozi da se prevlada takvo stanje.

Slični nesrazmjeri uočeni su i u kategoriji gradova kao i općina. Kada je o gradovima riječ, u njima po popisu stanovništva iz 2011. godine ukupno obitava 3.016.137 stanovnika. U kategoriji velikih gradova, dakle onih iznad 35.000 stanovnika, imamo ukupno 18 gradova, od čega su samo tri s više od 100.000 stanovnika.

Najveći postotak gradskog stanovništva imaju gradovi od $10.000-15.000$ stanovnika, njih 33,07\%, te od 15.000 - 20.000 stanovnika, njih 23,62 \%.

U 429 općina, po popisu iz 2011. godine, najveći broj stanovnika živio je u onima veličine od 2501 - 3000 stanovnika, čiji se broj stanovnika kretao na razini 155.295 ili $13,05 \%$, zatim onih od 2000 - 2500 stanovnika u kojima je živjelo 139.421 stanovnika ili 14,69 \%, te u općinama od 3500 - 4000 stanovnika ili 8,16 $\%$ od ukupnog broja općinskog stanovništva u Republici Hrvatskoj.

Podaci pokazuju da se radi o izrazito velikom broju jedinica lokalne samouprave u Republici Hrvatskoj koja pokazuje veliku usitnjenost i fragmentiranost. Ipak, bilo bi neodgovorno zaključiti da postojeći sustav lokalne samouprave u RH zaslužuje samo i isključivo negativno konotirane ocjene, pa sukladno tome, valja izbjegavati generalizirane zaključke.

Naime, hrvatska je lokalna samouprava u relativno kratkom vremenskom razdoblju polučila značajne pomake, posebice na planu komunalne infrastrukture, obrazovnog, prometnog, telekomunikacijskog, energetskog, plinofikacijskog i drugog područja.

Činjenica je kako se u metodološkom smislu općine mogu uspoređivati s općinama, gradovi s gradovima i županije sa županijama i da tu postoje velike neusklađenosti. 
Glede financijskih pokazatelja, prosječni rashod po stanovniku županija iznosio je 1052 kune, općina 2979 kuna i gradova 5141 kunu, što odražava i njihove različite nadležnosti. ${ }^{6}$

Financijski, proračunski podaci ukazuju na prevalentan utjecaj sljedećih čimbenika:

- $\quad$ presudan utjecaj položaja uz more na financijsko stanje gradova i općina;

- c česte velike neusklađenosti između prihoda i rashoda lokalnih jedinica unutar jedne godine;

- česte velike oscilacije prihoda i rashoda lokalnih jednica iz godine u godinu;

- $\quad$ neadekvatne kriterije pri određivanju statusa općina i gradova. ${ }^{7}$

Međunarodnopravni kriterij lokalne samouprave u RH ograničen je prvenstveno odredbama temeljnog akta, a to je Europska povelja o lokalnoj samoupravi koju je Republika Hrvatska konačno ratificirala 2008. godine.

Svakako, određeni prostor slobode u formiranju institucije lokalne samouprave omogućuju primjerice načela supsidijarnosti, proporcionalnosti te institucionalne autonomije država članica.

Da ne bismo upali u opasnost pukog ponavljanja već dobro poznatih ocjena o stanju lokalne samouprave u Republici Hrvatskoj, čini nam se da bi iz metodičkih razloga bilo uputno usmjeriti se na stanje u nama najbližoj Splitsko-dalmatinskoj županiji koja će nam poslužiti kao svojevrsna case-study.

Hrvatska je 2012. godine podijeljena na dvije regije - Jadransku Hrvatsku i Kontinentalnu Hrvatsku. Ova potonja, s gotovo 3.000.000 stanovnika, gotovo je dvostruko veća od Jadranske Hrvatske.

I V. Đulabić se pridružuje onim teoretičarima koji smatraju da se županije „tijekom dvadeset godina razvoja lokalne samouprave u Hrvatskoj nisu uspjele nametnuti kao značajna razina javnog upravljanja“".

Kao osnovne razloge takvog stanja ovaj autor nalazi u sljedećim činjenicama:

- relativno prostorno i populacijski male jedinice;

- broj županija je prevelik sa stajališta racionalne i objektivne regionalne diobe teritorija;

- županije, po njegovu mišljenju, ne odražavaju regionalni identitet građana;

- Hrvatska nema snažne regionalističke pokrete koji bi potaknuli transformaciju županija u veće i snažnije regije. ${ }^{9}$

6 Ott, Katarina - Bronić, Mihaela - Stanić, Branko: Ostvarenje proračuna općina, gradova i županija u 2016. godini, Newsletter, Institut za javne financije, Zagreb, br. 113/veljača, 2018., str. 1-2.

7 Ibidem, str. 3.

8 Đulabić, Vedran: „Položaj županija u statističkoj i političkoj regionalizaciji Hrvatske“, u: Dvadeset godina lokalne samouprave u Hrvatskoj, ur. Koprić, I. - Đulabić, V., Institut za javnu upravu, Priručnici za stručno usavršavanje, Zagreb, 2013., str. 183-200.

9 Ibidem, opširnije, str. 193-194. 
U svezi s rečenim upozorili bismo na činjenicu da u upravnoj i sociologijskoj literaturi postoji jasno razlikovanje između pojmova županija i regija, a o regionalizmu i njegovim povijesnim izazovima za hrvatsko društvo postoji značajna literatura, osobito povijesna i upravnopravna.

\section{SPLITSKO-DALMATINSKA ŽUPANIJA KAO JEDINICA ISTRAŽIVANJA}

Splitsko-dalmatinska županija druga je županija po prostornoj veličini u Republici Hrvatskoj. Sastoji se od ukupno 55 jedinica lokalne samouprave i to: 16 gradova i 39 općina. Status grada imaju sljedeća naselja: Hvar (4251 stanovnik), Imotski (4757 stanovnika), Kaštela (38.667 stanovnika), Komiža (1526 stanovnika), Makarska (13.834 stanovnika), Omiš (14.936 stanovnika), Sinj (24.826 stanovnika), Solin (23.926 stanovnika), Split (178.102 stanovnika), Stari Grad (2817 stanovnika), Supetar (3326 stanovnika), Trilj (9109 stanovnika), Trogir (13.260 stanovnika), Vis (1934 stanovnika), Vrgorac (6527 stanovnika) i Vrlika (2177 stanovnika).

Značajno je napomenuti da je na području Splitsko-dalmatinske županije zabilježen najveći nesrazmjer između dvaju gradova u Republici Hrvatskoj po kriteriju broja stanovnika, što znači da je Komiža s nešto preko 1500 stanovnika sto puta manja od središta Splitsko-dalmatinske županije - grada Splita. Prosječna gustoća naseljenosti Splitsko-dalmatinske županije u 2011. godini iznosila je 100,18 stanovnika/m2, što je iznad nacionalnog prosjeka $(75,71 \%)$ i iznad prosjeka Jadranske Hrvatske (57,2 \%). Zabrinjava činjenica da čak 31 jedinica ima gustoću naseljenosti manju od 50 stanovnika na $\mathrm{km} 2$, što ukazuje na značajne demografske probleme u većem dijelu Županije. Od toga je 18 jedinica lokalne samouprave u zaobalju te 12 na otocima.

Zemljopisno, Splitsko-dalmatinska županija smještena je na središnjem dijelu jadranske obale. Proteže se od Vrlike na sjeveru do najudaljenijeg hrvatskog otoka Palagruže na jugu, od Marine na zapadu do Vrgorca na istoku.

Otočno područje Županije sastoji se od 74 otoka i 57 hridi i grebena. Veličinom i naseljenošću izdvaja se pet otoka, a to su Čiovo, Šolta, Brač, Hvar i Vis. Naseljeno je još šest otoka: Veli Drvenik, Mali Drvenik, Sv. Klement, Šćedro, Biševo i Sv. Andrija.

Vodeći hrvatski autoritet na području demografije Alica Wertheimer-Baletić zaključuje nekoliko važnih stavova: „Prvo, Hrvatska nakon 1990. pokazuje slijedeće značajke: negativnu ukupnu demografsku bilancu jer ima ukupnu depopulaciju, odnosno njezin se agregatni kvantitativni rezultat iskazuje u smanjivanju ukupnog broja stanovnika. Drugo, Hrvatska istovremeno bilježi i prirodnu depopulaciju uvjetovanu većim brojem umrlih osoba u odnosu na broj živorođene djece. Treće, Hrvatska istovremeno bilježi i negativan migracijski saldo koji je uvjetovan većim brojem iseljenih osoba u odnosu na broj doseljenih i indikator je niske razine ekonomskog razvoja u odnosu na zapadnoeuropske zemlje. Činjenica je pri tome 
da se negativni migracijski saldo Hrvatske, napose zbog gospodarske recesije, nakon 2008. godine izrazito povećao. Determinira ga sve veći broj iseljenih osoba ne samo u emigraciju, uvjetuje pogoršanje demografskih i ekonomsko-socijalnih obilježja i struktura autonomnog stanovništva naše zemlje. Odlaze pretežno mladi visokoobrazovani ljudi konjunkturnih suvremenih zanimanja za kojima postoji visoka potražnja u visokorazvijenim zemljema“".10

Stopa nezaposlenosti u Splitsko-dalmatinskoj županiji značajno je viša od prosjeka Republike Hrvatske. Jedan od čimbenika koji negativno utječe na razinu nezaposlenosti jest vrlo niska razina mobilnosti radne snage u odnosu na zahtjeve tržišta rada. S druge strane, prisutan je trend odljeva obrazovane i sposobne radne snage, što nije specifikum samo ove županije, nego predstavlja dominantan trend na razini Republike Hrvatske.

Gospodarstvenu strukturu Županije karakterizira iznadprosječan broj aktivnih pravnih osoba u području poslovanja nekretninama, administrativnih i pomoćnouslužnih djelatnosti, pružanja smještaja, te pripreme i usluživanja hrane, prijevoza i skladištenje. Prema broju izgrađenih gospodarstvenih zona, kao i zona u pripremi, Splitsko-dalmatinska županija jedna je od vodećih u Republici Hrvatskoj.

Splitsko-dalmatinska županija prolazi kroz snažan proces deagrarizacije koji se očituje kroz smanjenje površine obrađenog poljoprivrednog zemljišta, kroz smanjenje broja domaćinstava kojima je poljodjelstvo glavni ili dodatni izvor prihoda, te kroz smanjenje broja stanovnika na svojim ruralnim područjima.

U oblasti kulture i obrazovanja postignut je značajan napredak. Tu mislimo prije svega na snažan razvoj Sveučilišta u Splitu osnovanog 1974. godine, u njegovim kvantitativnim i kvalitativnim pokazateljima. U području kulture posebno izdvajamo važnost i vrijednost Hvarskog kazališta, trećeg najstarijeg kazališta u Europi i ujedno najstarijeg europskog komunalnog kazališta, koje predstavlja spomenik najviše kategorije od nacionalnog značaja za Republiku Hrvatsku.

Zahvaljujući izuzetno vrijednim lokalitetima (starogradski Ager) objektima (Dioklecijanova palača) ili spomeničkim cjelinama (Salona, Trogir) pod zaštitom UNESCO-a, Splitsko-dalmatinska županija ima vrlo snažne atribute da se već u najkraćem vremenu tržišno pozicionira kao jedna od vodećih kulturno-turističkih destinacija Sredozemlja. Napomenimo ovom prilikom da susjedna Italija ima preko 50 \% ukupno zaštićenih spomenika pod ingerencijom UNESCO-a u svjetskim razmjerima.

Akutan problem Splitsko-dalmatinske županije predstavlja pitanje zaštite okoliša i pitanje odlaganja komunalno-gospodarskog otpada. Tu prije svega valja spomenuti sanaciju odlagališta otpada Karepovac u Splitu koja je u tijeku, kao i pitanje regionalnog centra za zbrinjavanje otpada u Lećevici blizu Splita, o kojem se raspravlja već puna dva desetljeća, ali se njegova realizacija odgađa do daljnjega, zbog jakog otpora ekoloških udruga i udruga civilnog društva. Pitanja onečišćenja

10 Wertheimer-Baletić, Alica: Demografska teorija, razvoj stanovništva Hrvatske i populacijska politika/Izbor tekstova, Meridijani, Samobor, 2017., str. 547. 
vode, posebice rijeka Jadro i Cetine, zaštite šuma, ornitoloških vrsta, također su goruća pitanja koja zahtijevaju stalnu skrb i pozornost.

Što se pak suradnje Splitsko-dalmatinske županije s drugim hrvatskim i inozemnim lokalnim područnim jedinicama samouprave tiče, riječ je o značajnom jačanju tog elementa samouprave pa u kontekstu ove tematike navodimo sljedeće sporazume koji su na snazi: Sporazum o suradnji između Autonomne pokrajine Furlanije, Venecije (Republika Italija), Sporazum o suradnji između departementa Herault (Republika Francuska) i Splitsko-dalmatinske županije, Sporazum o suradnji između Warminsko-Mazurskog vojvodstva (Republika Poljska) i Splitsko-dalmatinske županije te Sporazum o suradnji između Kijevske oblasne državne administracije Ukrajine i Splitsko-dalmatinske županije. Svakako da treba spomenuti i sporazume o suradnji i prijateljstvu s drugim hrvatskim županijama i to s Dubrovačko-neretvanskom, Šibensko-kninskom, Zadarskom županijom i Vukovarsko-srijemskom županijom.

Kao osobito pozitivnu okolnost u području suradnje, naglašavamo praksu aktualnog župana Splitsko-dalmatinske županije održavanja zajedničkih konzultativnih sastanaka sa svih 55 načelnika i gradonačelnika općina i gradova Splitsko-dalmatinske županije čime se jača koordinacija i mogućnost bržeg i efikasnijeg rješavanja uočenih problema.

Status općine u Splitsko-dalmatinskoj županiji imaju sljedeće jedinice: Sutivan (759 stanovnika), Milna (1100 stanovnika), Bol (1601 stanovnik), Civljane (277 stanovnika), Primorski Dolac (839 stanovnika), Dugopolje (3120 stanovnika), Baška Voda (2924 stanovnika), Brela (1971 stanovnik), Lokvičići (1037 stanovnika), Tučepi (1763 stanovnika), Podgora (2884 stanovnika), Lećevica (740 stanovnika), Nerežišće (868 stanovnika), Postira (1553 stanovnika), Okrug (3349 stanovnika), Zagvozd (1642 stanovnika), Podstrana (7341 stanovnik), Klis (4421 stanovnik), Pučišća (2224 stanovnika), Seget (4904 stanovnika), Cista Provo (3671 stanovnik), Podbablje (4904 stanovnika), Lovreć (2500 stanovnika), Muć (4074 stanovnika), Dicmo (2657 stanovnika), Otok (5782 stanovnika), Runovići (2643 stanovnika), Šolta (1479 stanovnika), Jelsa (3656 stanovnika), Zmijavci (2130 stanovnika), Šestanovac (2685 stanovnika), Hrvace (4116 stanovnika), Proložac (4510 stanovnika), Dugi Rat (7305 stanovnika), Gradac (3261 stanovnik), Prgomet (797 stanovnika), Selca (1977 stanovnika), Sućuraj (492 stanovnika), Zadvarje (277 stanovnika).

Najveća općina po broju stanovnika jest Podstrana s 9129 stanovnika, a najmanje su Civljane i Zadvarje. Od ukupnog broja općina, njih 14 iskazuje deficit u prihodovno/rashodovnoj stavci po stanovniku. Po prihodima per capita među općinama u RH vodi Sutivan (16.782 kn). Između 63 grada s prihodom po stanovniku nižim od 3500 kn u RH nalazi se i Grad Kaštela koji pripada Splitskodalmatinskoj županiji i s Pločama je jedini grad na moru ispod tog cenzusa. Od čak 37 općina s manje od 1000 stanovnika u RH, Civljane s 239 stanovnika i Zadvarje s 289 stanovnika, a obje su u sastavu Splitsko-dalmatinske županije, najmanje su jedinice lokalne samouprave u RH u kategoriji općina. 
Dr. sc. Duško Lozina: Refleksije o lokalnoj hrvatskoj samoupravi

Zbornik radova Pravnog fakulteta u Splitu, god. 55, 3/2018., str. 683.- 695.

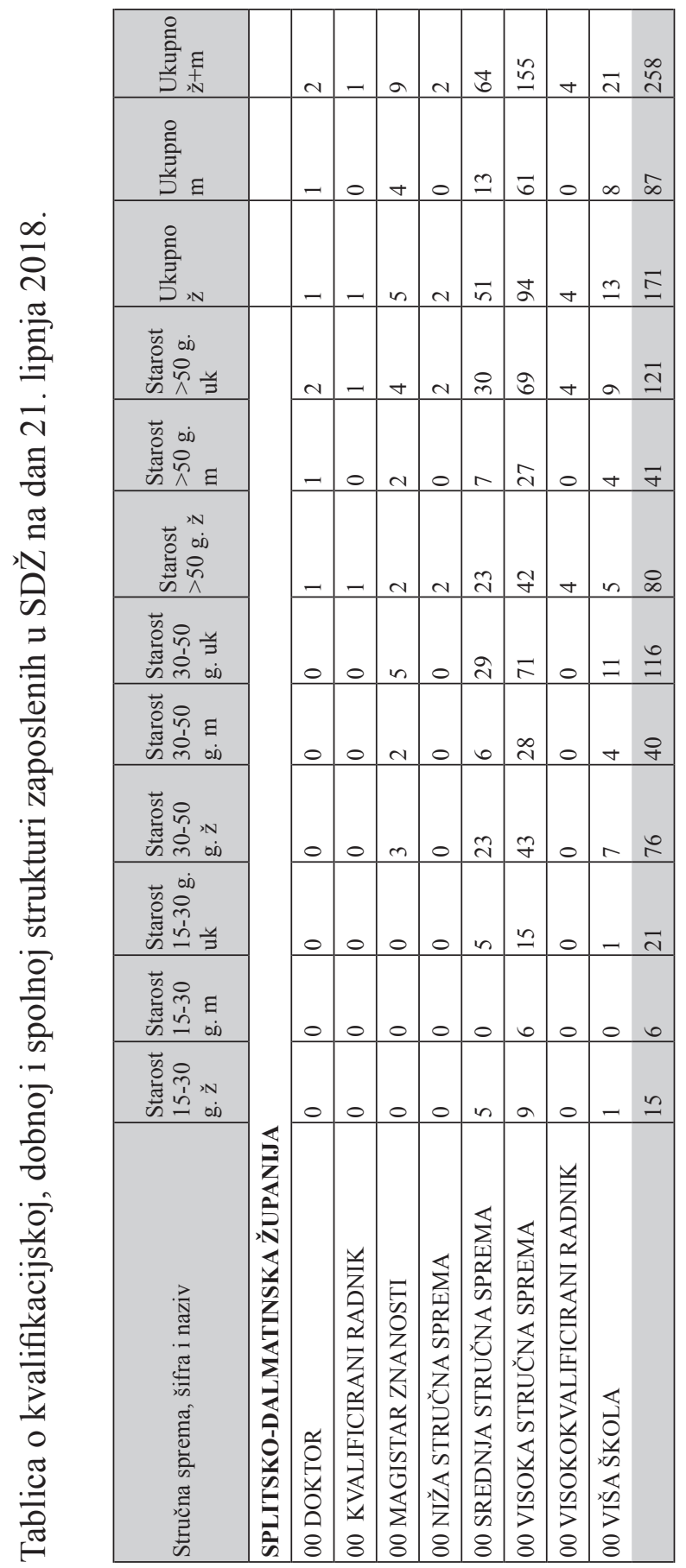


Split je kao administrativno, političko i kulturno središte Splitsko-dalmatinske županije 2016. godine imao 743,7 milijuna prihoda te kao drugi po veličini grad u Republici Hrvatskoj ostvaruje od ukupnih prihoda otprilike onoliko koliko 44 najsiromašnija grada zajedno. Proračun grada Splita za 2018. godinu iznosio je 1,025 milijardi kuna. Postoje gradovi s manje od 10 milijuna kuna ukupnih prihoda, a među njima su dva u sastavu Splitsko-dalmatinske županije, Komiža i Vrlika, što svjedoči o relativno slabom financijskom kapacitetu gradova.

Proračun Splitsko-dalmatinske županije za 2018. godinu iznosi 884.039.241,00 kn od čega se najveći iznos odnosi na prihode od poreza $219.600 .000,00$ kn, te pomoći iz inozemstva i od subjekata unutar općeg proračuna $233.337 .039,31 \mathrm{kn}$. Rashodi poslovanja Splitsko-dalmatinske županije u 2018. godini iznose 791.640.176,35 kn, od čega najveće stavke predstavljaju rashodi za zaposlene $360.309 .887,15 \mathrm{kn}$, te materijalni rashodi u iznosu od 291.413.129,88 kn.

Zbog veće preglednosti donosimo tablicu koja zorno svjedoči o stručnoj spremi, spolnoj pripadnosti i godinama staža zaposlenih u upravnim tijelima Splitskodalmatinske županije.

Razvidno je iz tablice da od ukupno 258 zaposlenih u upravnim tijelima Splitskodalmatinske županije u kategoriji stručne spreme prevladavaju oni s visokom stručnom spremom - njih 155. Dominantnu skupinu među njima čine oni koji imaju završen Pravni i Ekonomski fakultet. Iza njih su po brojnosti oni koji imaju završenu SSS - njih 64, dok je ostalih skupina relativno zanemariv broj. Kada je riječ o institucionalnom uređenju Splitsko-dalmatinske županije, treba reći da su radne jedinice Županije sljedeće:

- $\quad$ Ured župana;

- Tajništvo županije;

- $\quad$ Ured za unutarnju reviziju;

- Upravni odjel zajedničkih poslova;

- Poslovi namještenika;

- Informatički, materijalno-tehnički poslovi i civilna zaštita;

- Upravni odjel za gospodarstvo, EU-fondove i poljoprivredu;

- Odsjek za inovacije i razvoj malog i srednjeg poduzetništva;

- Odsjek za poljoprivredu, ribarstvo i ruralni razvoj;

- Odsjek za energetiku i promet;

- Upravni odjel za financije, proračunsko-računovodstveni poslovi; kontrola;

- Poslovi izvršenja proračuna i koordinacije razvoja sustava i unutarnjih

- Poslovi javne nabave;

- Upravni odjel za turizam i pomorstvo;

- Odsjek za turizam; 
- $\quad$ Odsjek za pomorstvo;

- $\quad$ Upravni odjel za prosvjetu, kulturu, tehničku kulturu i šport;

- Upravni odjel za graditeljstvo i prostorno uređenje te ispostave Hvar, Imotski, Makarska, Omiš, Sinj, Solin, Supetar, Trogir, Vis, Vrgorac;

- Poslovi postupanja s nezakonito izgrađenim zgradama;

- Upravni odjel za zdravstvo i socijalnu skrb; okoliša.

- Upravni odjel za komunalne poslove, komunalnu infrastrukturu i zaštitu

Istraživanje, koje je proveo istraživački tim Pravnog fakulteta u Splitu na uzorku od 3000 ispitanika, pokazalo je da više od $45 \%$ ispitanika ocjenjuje dosadašnju teritorijalnu podjelu Hrvatske na županije „lošom“ ili „,izuzetno lošom“. Uz to, preko $45 \%$ ispitanika izjašnjava se u prilog smanjenja broja županija, odnosno njihovu svođenju na nekoliko povijesnih regija. Ispitanici su posebno skloni radikalnom smanjenju broja općina, za što se izjasnilo preko $50 \%$ ispitanika. ${ }^{11}$

Ovo se istraživanje u potpunosti uklapa u gotovo jedinstveno i prevladavajuće mišljenje o nužnosti promjena teritorijalne organizacije lokalne samouprave $\mathrm{u}$ Republici Hrvatskoj.

\section{ZAKLJUČAK}

U radu smo pokušali pokazati kakvo je stanje lokalne i područne samouprave u Republici Hrvatskoj s posebnim osvrtom na stanje u Splitsko-dalmatinskoj županiji. Nedvojbeno, lokalna i područna (regionalna) samouprava važna su karika u višerazinskom modelu upravljanja i odlučivanja. Načela supsidijarnosti, decentralizacije i druga spomenuta načela snažno afirmiraju ovu instituciju, s obzirom na to da „europske integracije radikalno mijenjaju ulogu države“. ${ }^{12}$

Pokazali smo da lokalna i područna samouprava ovisi o nizu determinanti kao što su financijski, politički, povijesni, kulturološki, demografski, prometni i drugi čimbenici.

Osobitu pozornost nastojali smo pridati analizi Splitsko-dalmatinske županije ukazujući na njezine specifičnosti, ali i neke opće značajke koje dijeli s drugim županijama u Republici Hrvatskoj. Pritom naglasili smo da je svaka generalizacija tipa pozitivno/negativno metodički netočna.

Empirijska istraživanja pokazuju da građani, a njihovo je mišljenje važno, izražavaju visoki postotak suzdržanosti prema ovakvom teritorijalnom uređenju Republike Hrvatske, a upravna struka gotovo jedinstveno stoji na motrištu da su

11 Cvitan, Onesin: „Teritorijalni ustroj i regionalizacija Republike Hrvatske u kontekstu europskih integracija“, Zbornik radova Pravnog fakulteta u Splitu, 2010., str. 14.

12 Klüver, Heike: „Les lobbies dans la governance la main-invisible-du marche“, Pouvoirs, No. 149. Éditions du Seuil, Paris, str. 121-134. 
potrebne snažne reforme takvog sustava, u smislu smanjivanja postojećeg broja općina, gradova i županija.

Prof. Koprić u svojim radovima ističe da su glede budućnosti lokalne i područne (regionalne) samouprave mogući sljedeći scenariji:

- $\quad$ početni i zasad izgledni scenarij jest inercija;

- drugi scenarij je prilagodba formalnopravne regulacije sadašnjem stanju, posebno u odnosu na županije i općine, s otvaranjem mogućnosti regionalizacije;

- $\quad$ treći i najpoželjniji scenarij podrazumijeva ozbiljnu teritorijalnu reformu. ${ }^{13}$

Dodali bismo da je očekivanje kopernikanskog obrata u ovom području malo vjerojatno. Takav scenarij nije izgledan, barem nam se tako čini, do 2025 . godine, jer se tada po našim spoznajama planira istodobno održavanje lokalnih, parlamentarnih i predsjedničkih izbora, što može utjecati i na moguću novu konfiguraciju teritorijalnog uređenja Republike Hrvatske, ali je svakako poželjno očekivati poboljšanje funkcionalnih performansi lokalne i područne (regionalne) samouprave u našoj zemlji.

\section{Literatura}

Babac, Branko: „Oblikovanje hrvatskoga regionalnog političko-regionalnog, političkoupravnog ustrojstva u razmeđu suvremenosti, nacionalne tradicije i europeizacije - prethodni iskazi“", u: Zbornik radova - Teritorijalni ustroj i regionalizacija RH u kontekstu europskih integracija, PFS, Split, 2010., str. 53-84.

Christensen, Tom - Laegred, Per: Transcending New Public Management, The transformation of Public Sector Reforms, Ashgate Publishing Limited, Survey, England, 2009.

Cvitan, Onesin: „Teritorijalni ustroj i regionalizacija Republike Hrvatske u kontekstu europskih integracija“, Zbornik radova PFS 2010., str. 14.

Đulabić, Vedran: „Položaj županija u statističkoj i političkoj regionalizaciji Hrvatske“, u: Dvadeset godina lokalne samouprave u Hrvatskoj, ur. Koprić, I. - Đulabić, V., Institut za javnu upravu, Priručnici za stručno usavršavanje, Zagreb, 2013.

Klüver, Heike: „Les lobbies dans la governance la main-invisible-du marche“, Pouvoirs, Éditions du Seuil, Paris, No. 149., str. 121-134.

Koprić, Ivan - Musa, Anamarija, Lalić - Novak, Goranka: Europski upravni prostor, Institut za javnu upravu, Zagreb, 2012.

Koprić, Ivan: „Suvremeni trendovi u razvoju lokalne samouprave i hrvatska lokalna i regionalna samouprava“, u knjizi: Europeizacija hrvatske lokalne samouprave, Institut za javnu upravu, Priručnici za stručno usavršavanje, Zagreb, 2018.

Kruiyen, M. Peter - Genugten, van Marieke: „Creativity in Local Government: Definition and determinants“, Public Administration, No. 3/vol. 95., Wiley, Singapore, 2017.

13 Koprić, Ivan: kao pod 3., str. 1-56. 
Ott, Katarina - Bronić, Mihaela - Stanić, Branko: Ostvarenje proračuna općina gradova $i$ županija u 2015. godini, Newsletter, Institut za javne finacije, br. 113/veljača, Zagreb, 2018.

Pollitt, Christopher - Bouckaert, Geert: Public Management Reform - A Comparative Analysis, Oxford University Press, 2004.

Statistički ljetopis RH, Državni zavod za statistiku RH, Zagreb, 2017.

Wertheimer-Baletić, Alica: Demografska teorija, razvoj stanovništva Hrvatske $i$ populacijska politika, Izbor tekstova, Meridijani, Samobor, 2017.

\section{Internetski izvori:}

https:/hr.wikipedia.org/dodatak: popis_gradova_i_općina_u_RH_po županijama, pregledano dne 20. svibnja 2018.

https:/hr.m.wikipedia.org/wiki/Splitsko-dalmatinska_županija

\section{SUMMARY}

The key aim of this paper is to demonstrate a few main pathsthrough which goes the system of local self-goverment in Croatia. Europeanization process more and more encompasses and shapes croatian local self goverment including implementation of new standards of work such as democratization and dispersion processes, public participation, transparency, openness and also specialities, informatization and digitalization. These are the fundamental values of admininistrative doctrines like new public managment, ,good governance“ ect. In the context of this subject of matter, we have put a special emphasis on some aspects of organizational structure of Split-Dalmatia County, underlining data about qualifications, age of employees in administrative structures of County and some data about financial-budget capacity of communities, towns and County.

Key words: local self goverment, administrative doctrines, values of local self-governance, financial budget capacity, europeanization 